\title{
Development of a Playful Tool to Application in Basic Education Through Educational Tutorial Program of Biochemistry's (ETP)
}

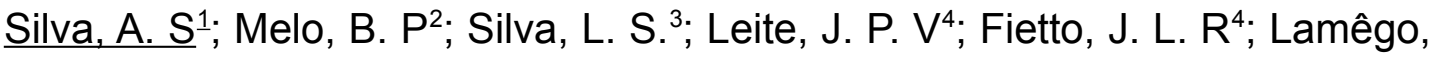 \\ M. R. $A^{4}$; Moraes, G. H. $K^{5}$. \\ ${ }^{1}$ Master's Degree Student in Agricultural Biochemistry from UFV; ${ }^{2}$ Member of \\ ETP-Biochemistry UFV; ${ }^{3}$ Nursing Student from UFV; ${ }^{4}$ Professor of \\ Biochemistry and Molecular Biology Department (BBD) from UFV; ${ }^{5}$ \\ Agronomist, professor at BBD, work's advisor.
}

\begin{abstract}
INTRODUCTION: Playful activities can be a great method to become permanent knowledge in specific and complexes themes, according SOARES (2004). This work treats about the construction of a game to be used in teacher's qualification by Educational Tutorial Program in Biochemistry (ETP). OBJECTIVES: Evaluate the ludicity and capacity of a game to construct cognitive memories and become easy the familiarization process between the teachers and the molecular models. MATERIALS AND METHODS: A previous study of games developed in a matter from Biochemistry Bachelor Deegre was done to evaluate what's the better game as clearness, dynamic, interaction and duration's time. After the study, a Memory Card game was chosen to integrate the activities applied by ETP in workshops. It is composed by thirty six cards divided in texts and images cards, being the pair constituted necessarily by one image and one text card. The images on the cards are based in kit's $^{(*)}$ pieces - nucleotides, amino acids, DNA, RNA, etc. Applying the game before the manipulation, is expected that teachers link the theory and the model by the previous familiarization. To evaluate it, questionaries were applied with questions about the efficacy of the assimilation using the game as a previous activity before the effective manipulation. RESULTS AND DISCUSSION: Datas show that $83,3 \%$ of teachers thought interesting the application of game how a familiarization step and they affirm that this method is effective to make them closer to the pieces. In addition, the informations brought in cards can become solid basic concepts in Molecular Biology and allow that the student memorizes it of an easier way. CONCLUSIONS: These results are a proof that games are able to rise up cognitive memory building, remedy assimilation and memorization deficit and build long time memories. In addition, a playful methodology provides an informal set that become easier the approach of massive contents in science.
\end{abstract}

Keywords: playful methodology, game, memory cards, molecular kit, Biochemistry Education.

Supported by: CAPES

\section{Notes:}

$\left(^{*}\right)$ Called "Construindo as Moléculas da Vida: DNA-mRNA-Proteína", the kits were developed by researches men from Instituto de Física da USP - São Carlos.

Bibliographic References:

SOARES, M. H. F. B. Playful tool in Chemistry: games and activities applied to the teaching of Chemistry. Universidade Federal de São Carlos, 2004. 